\title{
PERFORMANCE OF MAIZE (ZEA MAYS) CULTIVARS AS INFLUENCED BY GRADE AND APPLICATION RATE OF ORGANO-MINERAL FERTILISER IN A TRANSITORY RAIN FOREST
}

\author{
Aderibigbe ${ }^{1}$ S.G., Sakariyawo ${ }^{1 *}$ O.S., Kasali ${ }^{1}$ A.O. \\ 1Department of Plant Physiology and Crop Production, Federal University of Agriculture, \\ Abeokuta, (FUNAAB), P.M.B. 2240, Ogun State, Nigeria \\ *Corresponding author: adetanwa@yahoo.co.uk Tel:+2347030890180
}

\section{ABSTRACT}

Field trials were conducted in a transitory humid rain forest, Abeokuta, Nigeria (Latitudes $7^{\circ} 15^{\prime} \mathrm{N}$, 3. 25'E, altitude 144 above sea level) in early wet cropping seasons of 2014 (site A) and 2015 (site B). The trials were aimed at investigating the effects of application rates of grades of organomineral fertiliser on maize (Zea mays)cultivars. The trials were in split-split plot arrangement fitted into randomised complete block design and replicated three times. In the main plot was variety \{Oba super 2 (hybrid) and Suwan 1[open pollinated variety (OPV)]\}, sub-plot consisted of grade of organo-mineral fertiliser $(A, B, C)$, while the sub-sub plot was made of application rate $(0,2.5$ and 5.0 t ha- $\left.^{-1}\right)$. Oba super 2 had significantly $(P<0.05)$ more assimilatory surface, with more 100 grain $(7.13 \mathrm{~g})$ and ear weight $(0.08 \mathrm{~kg})$, harvest index $(37.60 \%)$ than OPV maize cultivar (Suwan 1) in 2015. Maize cultivars sown with grade $B$ organo-mineral fertiliser had delayed tasselling (57.50 days) and silking (66.33 days) compared to when sown with other organo-mineral grades. Increasing application rates of organo-mineral fertiliser resulted in increased assimilatory surface and a higher grain yield and its attributes in both years.

Keywords: Hybrid, Open Pollinated Maize, Transitory Rain Forest, Silking, Tasselling

\section{INTRODUCTION}

In North America there has been a steady rise in the yield potential of hybrid maize compared to the open pollinated varieties (OPV) (Tollenaar and Lee, 2006). Genetic improvement in conjunction with good management practise have played a fundamental role on this increase (Tollenaar and Lee, 2006). The physiological basis that underpins this genetic improvement has 
been attributed to both canopy and root architecture, especially under high population density (Hammer et al., 2009). The hybrids have been characterised to have high yield potentials (Tollenaar and Lee, 2006) due mainly to higher assimilatory surfaces and high leaf angle that could facilitate diffusion of light into the lower portion of the canopy (Duncan et al., 1967). Other physiological basis has been reported to be linked to stay green leaf at the most critical stage of maize growth and increased duration of grain filling period (Tollenaar and Lee, 2006). Abayomi et al., (2006) reported that the yield advantage observed in the hybrid maize could be linked to their higher leaf growth, leaf area duration and effective leaf area than the OPV. However, among resource challenged farmers in the tropical region of Africa purchase of hybrid maize cultivar is beyond their financial means. Most have thus resolved to the use of OPV.

Humid rainforest is characterised by high precipitation and temperature. With climate change, it is expected that there would be variation in rainfall and temperature pattern. The variation in these environmental variables could be as a result of increased atmospheric carbon dioxide that accompanies climate change (Ainsworth, 2008). Under elevated carbon dioxide $\left(\mathrm{CO}_{2}\right)$ increased temperature could lead to increased evapotranspiration and a disruption in plant water balance, which will consequently affect the growth of maize at the most critical period. Maize has been reported to have low remobilisation efficiency and reduced plasticity of seed weight to assimilate availability especially under the influence of abiotic stress (Borrás et al., 2004), with the negative implication on its performance. Soils in humid rain forest are highly susceptible to leaching of macronutrients and are low in nutrient content due to intense weathering (Lathwell and Grove, 1986). Together this could compromise the growth and development of maize crop. The application of inorganic fertiliser is expensive and has the potential to negatively impact environment if not properly used. The low usage of inorganic fertiliser in some parts of the country was also ascribed to the educational status of farmers, farm size and contact with extension workers (Adenuga et al., 2012). Organic fertiliser can be used as an alternative solution to this problem, but their bulkiness and slow releasing property could pose a challenge. Reports have indicated that the use of organo-mineral fertiliser in maize and melon gave high relative agronomic efficiency, phosphorus recovery efficiency and added benefit than inorganic fertiliser in medium axicpaleustalf and weakly acid typicpaleudalf soil types (Akinrinde et al., 2005). Similar pattern was also observed on cucumber in the rainforest agroecology of Nigeria, where it was observed that they had the added benefit of retaining moisture in the soil (Olaniyi et al., 2009). 
In order to address the problem of bulkiness of natural organic manures like poultry droppings and cow dungs, fertiliser companies have started producing organo-mineral fertilisers. However, few literatures exist on how different grades and application rates of organo-mineral fertiliser affect the performance of maize cultivar in a transitory rain forest. The availability of such information would shed more light on sustainable maize production. It would allow farmers to implement the right application rates of this type of organo-mineral fertiliser. It would provide information on the comparative agronomic advantage of hybrid maize and OPV in this zone.

\section{MATERIALS AND METHODS}

\section{Characterisation of location and experimental site}

Field experiments were conducted at the Teaching and Research Farm of Federal University of Agriculture, Abeokuta (FUNAAB), Ogun State (Latitudes 7॰15'N, 325'E, altitude 144 above sea level). They were conducted during the wet seasons at site A and B in the year 2014 and 2015 respectively in the same location. The agrometeological data were sourced from the Department of Agrometeorological and Water Management, Federal University of Agriculture, Abeokuta. Soil $\mathrm{pH}$ was determined using glass electrode $\mathrm{pH}$-meter as described by McLean, (1982) in soil:water suspension (1:1). Soil organic carbon was determined using the wet oxidation method as described by Walkley and Black (Allison, 1965). Soil total nitrogen was determined using the modified micro Kjeldahl digestion technique (Jackson, 1962).Available phosphorus was determined according to Bray-1 method as described by Landor, (1991).

\section{Experimental Treatments and Design}

The treatments had three grades of organo-mineral fertilisers (A, B and $C)$ that were applied at three rates $\left(0,2.5\right.$ and 5.0 t ha- $\left.^{-1}\right)$ on two maize cultivars (Oba super 2 and Suwan 1). Oba super 2 was a hybrid while Suwan 1 was OPV maize. The field trial was a split-split plot arrangement fitted into randomised complete block design and replicated three times. The main plot consisted of cultivar, with grades of the organo-mineral fertiliser in the sub plot, while application rates were in the sub-sub plot. Organo-mineral fertiliser used was sourced from Gateway Fertiliser plant Kotopo, Abeokuta, Ogun State. The percentage of $\mathrm{N}$ in the organo-mineral fertiliser grades used was $5 \%, 10 \%$ and $15 \%$ for grade $A, B$ and $C$ respectively. Application rate of $2.5 \mathrm{t} \mathrm{ha}^{-1}$ of organo-mineral fertiliser was equivalent to $\mathrm{N}$ application rates of $62.5 \mathrm{~kg} \mathrm{~N} \mathrm{ha}^{-1}, 87.5 \mathrm{~kg} \mathrm{~N} \mathrm{ha}^{-1}$, 
and $110 \mathrm{~kg} \mathrm{~N}^{-1} \mathrm{a}^{-1}$ or grade $\mathrm{A}, \mathrm{B}$ and $\mathrm{C}$ respectively. While application rate of $5.0 \mathrm{tha}^{-1}$ of organomineral fertiliser was equivalent to $\mathrm{N}$ application rates of $125 \mathrm{~kg} \mathrm{~N} \mathrm{ha}^{-1}, 175 \mathrm{~kg} \mathrm{~N} \mathrm{ha}^{-1}, 220 \mathrm{~kg} \mathrm{~N}$ ha- ${ }^{-1}$ for type $A, B$ and $C$ respectively. The control plot received no fertiliser application. There was variation in the chemical composition of the organo-mineral fertiliser used. The order of chemical composition of the major macro and micro nutrients was organo-mineral fertiliser grade $\mathrm{C}>\mathrm{B}>\mathrm{A}$ except $\mathrm{Mg}$, where the order of nutrient composition was $\mathrm{A}>\mathrm{B}>\mathrm{C}$. The $\mathrm{pH}$ of all the grades of organo-mineral fertilisers used was similar (Table 1). 
Table 1: Chemical composition of organo-mineral fertilizer grades ( $A, B$ and $C)$

\begin{tabular}{|c|c|c|c|c|c|c|c|c|c|c|c|c|}
\hline $\begin{array}{l}\text { Variables / } \\
\text { Grade }\end{array}$ & $\mathrm{pH}$ & $\begin{array}{l}\text { Organic } \\
\text { carbon } \\
\mathrm{g} \mathrm{kg}^{-1}\end{array}$ & $\begin{array}{l}\text { Total N } \\
\mathrm{g} \mathrm{kg}^{-1}\end{array}$ & $\begin{array}{l}\mathrm{P} \\
\mathrm{cmol} \mathrm{kg}^{-1}\end{array}$ & $\begin{array}{l}\mathrm{K} \\
\mathrm{cmol} \mathrm{kg}^{-1}\end{array}$ & $\begin{array}{l}\mathrm{Ca} \\
\mathrm{cmol} \mathrm{kg}^{-1}\end{array}$ & $\begin{array}{l}\mathrm{Mg} \\
\mathrm{cmol} \mathrm{kg}^{-1}\end{array}$ & $\begin{array}{l}\mathrm{Na} \\
\mathrm{cmol} \mathrm{kg}^{-1}\end{array}$ & $\begin{array}{l}\mathrm{Mn} \\
\mathrm{cmol} \mathrm{kg}^{-1}\end{array}$ & $\begin{array}{l}\mathrm{Zn} \\
\mathrm{cmol} \mathrm{kg}^{-1}\end{array}$ & $\begin{array}{l}\mathrm{Fe} \\
\mathrm{cmol} \mathrm{kg}^{-1}\end{array}$ & $\begin{array}{l}\mathrm{Cu} \\
\mathrm{cmol} \mathrm{kg}^{-1}\end{array}$ \\
\hline$A$ & 7.8 & 6.88 & 2.5 & 1.73 & 0.54 & 0.16 & 0.19 & 0.45 & 0.13 & 0.03 & 0.07 & 0.05 \\
\hline B & 7.2 & 7.03 & 3.5 & 2.00 & 0.56 & 0.17 & 0.18 & 0.44 & 0.12 & 0.03 & 0.07 & 0.03 \\
\hline C & 7.9 & 7.18 & 4.4 & 2.22 & 0.62 & 0.18 & 0.17 & 0.50 & 0.13 & 0.03 & 0.09 & 0.04 \\
\hline
\end{tabular}

Table 2: Pre-planting physical and chemical soil properties for 2014 and 2015 experimental site

\begin{tabular}{|c|c|c|c|c|c|c|c|c|c|c|c|c|c|c|c|c|}
\hline Year & $\begin{array}{l}\text { Clay } \\
\%\end{array}$ & $\begin{array}{l}\text { Sand } \\
\%\end{array}$ & $\begin{array}{l}\text { Silt } \\
\%\end{array}$ & $\begin{array}{l}\text { Textural } \\
\text { class }\end{array}$ & $\mathrm{pH}$ & $\begin{array}{l}\text { Organic } \\
\text { Carbon } \\
\%\end{array}$ & $\begin{array}{l}\text { Total N } \\
\%\end{array}$ & $\begin{array}{l}\mathrm{P} \\
\mathrm{cmol} \mathrm{kg}^{-1}\end{array}$ & $\begin{array}{l}\mathrm{K} \\
\mathrm{cmol} \mathrm{kg}^{-1}\end{array}$ & $\begin{array}{l}\mathrm{Ca} \\
\mathrm{cmol} \mathrm{kg}^{-1}\end{array}$ & $\begin{array}{l}\mathrm{Mg} \\
\mathrm{cmol} \\
\mathrm{kg}^{-1}\end{array}$ & $\begin{array}{l}\mathrm{Na} \\
\mathrm{cmol} \mathrm{kg}^{-1}\end{array}$ & $\begin{array}{l}\mathrm{Mn} \\
\mathrm{cmol} \mathrm{kg}^{-} \\
1\end{array}$ & $\begin{array}{l}\mathrm{Zn} \\
\mathrm{cmol} \\
\mathrm{kg}^{-1}\end{array}$ & $\begin{array}{l}\mathrm{Fe} \\
\mathrm{cmol} \mathrm{kg}^{-1}\end{array}$ & $\begin{array}{l}\mathrm{Cu} \\
\mathrm{cmol}\end{array}$ \\
\hline 2014 & 9.40 & 84.40 & 6.20 & $\begin{array}{l}\text { Sandy } \\
\text { loam }\end{array}$ & 6.4 & 0.456 & 0.147 & 0.64 & 0.02 & 0.01 & 0.01 & 0.05 & 0.02 & 0.01 & 0.01 & 0.01 \\
\hline 2015 & 4.70 & 88.50 & 6.80 & sandy & 6.65 & 1.00 & 0.08 & 0.72 & 0.01 & 0.21 & 0.04 & 0.02 & 1.57 & 0.09 & 0.06 & 0.01 \\
\hline
\end{tabular}




\section{Cultural Practices}

The field was ploughed twice and harrowed once. Planting was conducted on the $24^{\text {th }}$ and $27^{\text {th }}$ of June in the years 2014 and 2015 respectively. Planting materials were sourced from Ogun State Ministry of Agriculture, Asero, Abeokuta. Three seeds were sown per hole at a depth of $2 \mathrm{~cm}$ with a spacing of $75 \times 50 \mathrm{~cm}$. The seedlings were later thinned to 2 plants per stand 3 weeks after planting (WAP). Missing stands were supplied at this period. The organo-mineral fertiliser was applied 2 WAP. The gross plot size was $3 \times 4 \mathrm{~m}$, while the net plot size was $2 \times 2 \mathrm{~m}$. The plots were separated from each other by $0.5 \mathrm{~m}$ pathway while each block was separated by $1 \mathrm{~m}$. Weeding was done manually at 3 and 6 WAP.

\section{Sampling and data collection}

A composite soil sample was randomly collected at $0-20 \mathrm{~cm}$ depth across the field to determine pre-planting physical and chemical properties of the soil at the experimental sites. All growth parameters were taken at 4, 8 and 12 WAP. Yield and its attributes were taken at physiological and harvest maturity. Five plants were randomly sampled from each net plot to determine growth, development, grain yield and its attributes. The growth parameters determined were leaf area, leaf area index and stover weight. Leaf area was determined according to the protocol proposed byDwyer and Stewart, (1986). Days to $50 \%$ anthesis, days to $50 \%$ silking, Anthesis-Silking Interval (ASI), cob length, cob girth, 100 grain weight, shelling percentage, harvest index and grain weight were determined according to standard agronomic practises.

\section{Statistical analysis}

Data collected were subjected to Mixed Model Analysis of Variance (ANOVA) for each year. Significant means were separated using Least Significant Difference (LSD) at $5 \%$ probability level. Data collected were checked for the violation of ANOVA assumption visually by plotting residual against fitted values. Discrete data were transformed using square root transformation

prior to analysis. The statistical package used for the analysis was GENSTAT $12^{\text {th }}$ Edition (Payne et al., 2009).

\section{RESULTS}

Both years had similar temperature pattern during the cropping seasons (Fig.1). The mean temperature during the cropping season was in the range $27.5^{\circ} \mathrm{C}$ (Nov)-25.6 ${ }^{\circ} \mathrm{C}$ (Aug). The cropping seasons at both years experienced bimodal rainfall pattern (Fig.2). Increase in the total 
rainfall experienced at the beginning of the cropping season (June) resulted in decrease in the intensity of rainfall at August (August break), with a subsequent increase in the amount rainfall which eventually declined in November in both years. During the 2014 cropping season, the highest amount of rainfall $(205.9 \mathrm{~mm}$ ) was observed in October (Fig.2). In the next cropping season the highest amount of rainfall $(165.1 \mathrm{~mm}$ ) was observed in September (Fig.2). Both years had the least amount of rainfall in November. The soil physical and chemical characteristics of the two sites used were slightly different (Table 2). Soil pH for both sites was similar (slightly acidic). The texture of site $A$ used in 2014 was sandy loam, while that of site $B$ used in 2015 was sandy. The amount of N present in the soil was $0.147 \%$ and $0.08 \%$ for the site $A(2014)$ and $B$ (2015) respectively. Conversely percentage organic carbon was more in $B(1.00 \%)$ than the site A $(0.356 \%)$. Similar pattern was observed on the amount of available $\mathrm{P}, \mathrm{Ca}$ and $\mathrm{Mg}$. More sodium $\left(0.05 \mathrm{cmol} \mathrm{kg}^{-1}\right)$ was observed in the site $A$ than site $B\left(0.02 \mathrm{cmol} \mathrm{kg}^{-1}\right)$. The amount of $\mathrm{K}$ present in the soil was $0.02 \mathrm{cmol} \mathrm{kg}^{-1}$ and $0.01 \mathrm{cmol} \mathrm{kg}^{-1}$ in site $A$ and $B$ respectively.

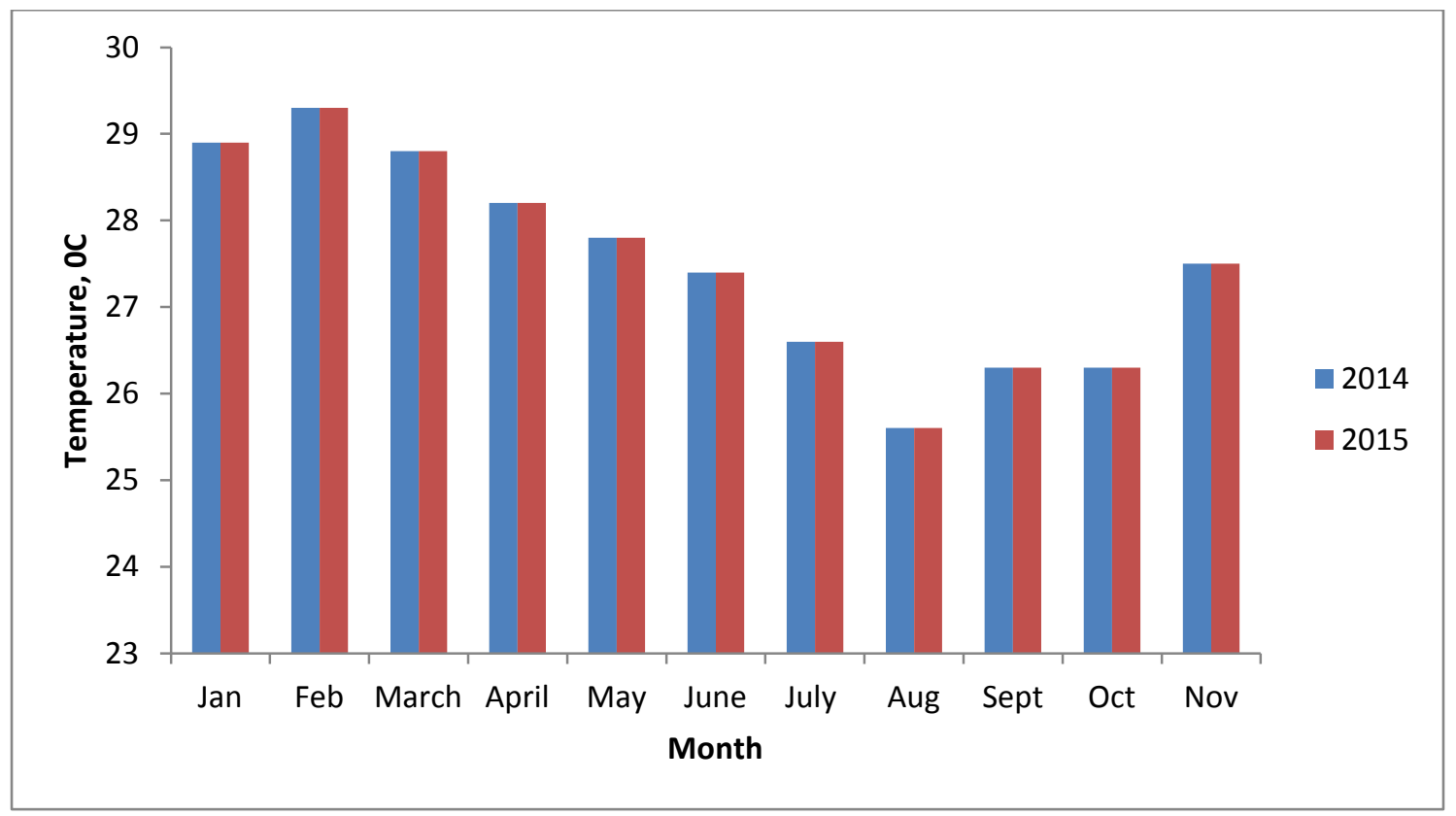


Figure 1: Temperature distribution for the years 2014 and 2015 cropping seasons

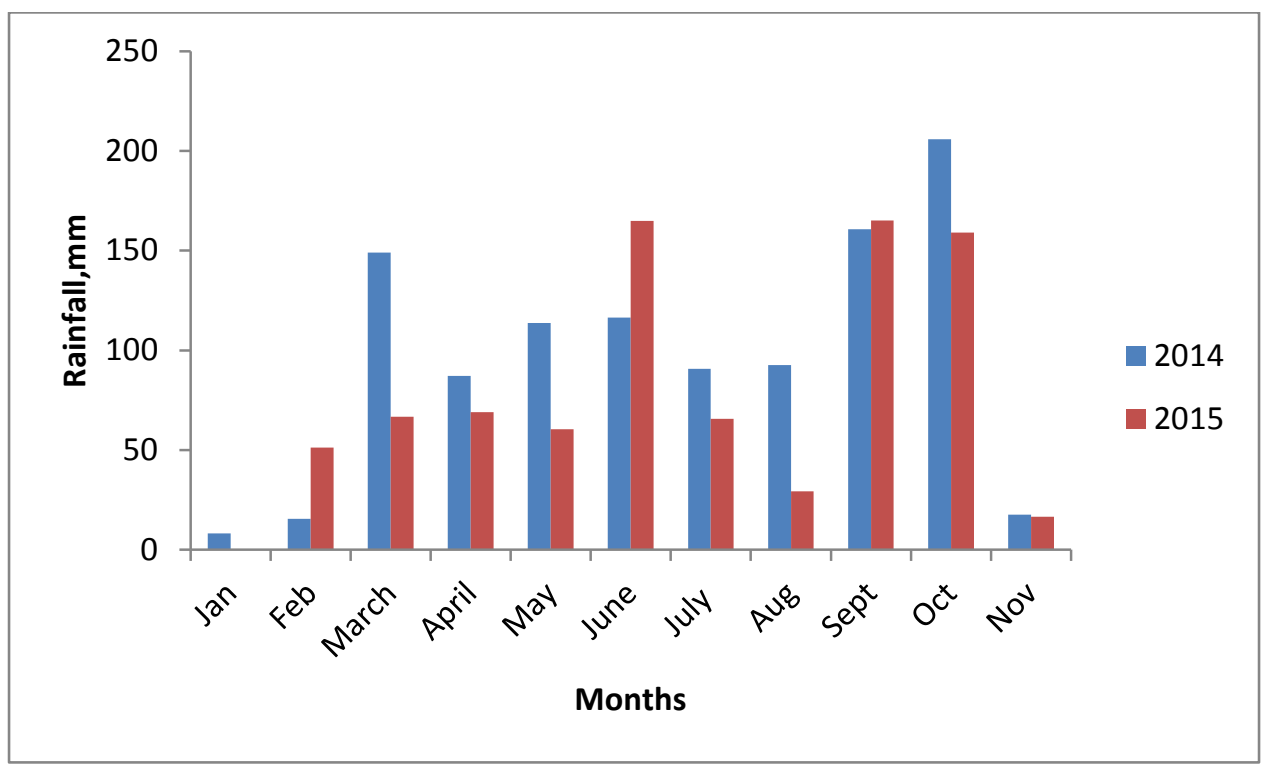

Figure 2: Rainfall distribution for the years 2014 and 2015 cropping seasons

There were no significant differences among the varieties on the leaf area at all sampling period in the year 2014 (Table 3). Similar pattern was observed on other vegetative (Table 4), phenological (Table 5) and reproductive growth (Tables 6 and 7) variables at all sampling period in the same year. The hybrid maize Oba super 2 had significantly $(P<0.05)$ higher leaf area $\left(272.80 \mathrm{~cm}^{2}\right)$ than the OPV $\left(186.10 \mathrm{~cm}^{2}\right)$ (Suwan 1) maize cultivar at 4 WAP in the year 2015 (Table 3). In the same year similar pattern was observed on harvest index (37.60\%) (Table 6), 100 grain weight $(7.13 \mathrm{~g})$, cob weight $(0.08 \mathrm{~kg})$ and grain yield $\left(1655 \mathrm{~kg} \mathrm{ha}^{-1}\right)$ (Table 7$)$.

Fertiliser grades had significant effect on leaf area at 12 WAP (2014) in the order A > B > C (Table 3). In the same year maize cultivars sown with fertiliser grade $B$ attained days to $50 \%$ tasseling (57.50 days) and $50 \%$ silking (66.33 days) later than those cultivars sown with other grades of organo-mineral fertilisers (Table 5). Maize cultivars sown with organo-mineral fertilisers grade $\mathrm{A}$ and $\mathrm{C}$ attained days to $50 \%$ tasseling and days to $50 \%$ silking respectively earlier than 
other maize cultivars sown with other grade of organo-mineral fertiliser (Table 5). Grades of organo-mineral fertilisers had no significant effect on grain yield and its components in both years (Tables 6 and 7).

In the year 2014 increasing application rates of organo-mineral fertiliser resulted in a significant increase in leaf area of maize cultivars at all periods of investigation (Table 3). Similar pattern was repeated in the following year except at 4 WAP where it was observed that applying organomineral fertiliser beyond $2.5 \mathrm{t} \mathrm{ha}^{-1}$ resulted in a significant decrease in leaf area (Table 3). Leaf area index in both years at all periods of investigation responded in a similar pattern to increasing application rates of organo-mineral fertiliser as leaf area (Table 4). It was observed that with increasing application rates of organo-mineral fertiliser maize cultivars attained days to $50 \%$ tasseling earlier (both years). Similar pattern was observed on days to $50 \%$ silking (2015). Maize cultivars had similar duration of anthesis-silking interval in year 2014, however no significant effect was observed on this variable in the following year with increasing application rates of organo-mineral fertiliser (Table 5). Increasing application rates of organo-mineral fertiliser resulted in an increased stover weight (2014 and 2015) and shelling percentage (2014). However, it was observed that at application rates of $2.5 \mathrm{t} \mathrm{ha}^{-1}$ and $5.0 \mathrm{t} \mathrm{ha}^{-1}$ maize cultivars displayed similar stover weights (2014 and 2015) and shelling percentage (2014) (Table 6). Cob weight, 100 grain weight and grain yield in both years increased with increasing application rates of organo-mineral fertiliser (Table 7). 
Table 3: Effect of organo-mineral fertiliser grade and application rate on leaf area of maize cultivars at 4, 8, 12 WAP (2014 and 2015$)$

\begin{tabular}{|c|c|c|c|c|c|c|}
\hline & \multicolumn{3}{|c|}{2014} & \multicolumn{3}{|c|}{2015} \\
\hline & Leaf area 4 & Leaf area 8 & Leaf area 12 & Leaf area 4 & Leaf area 8 & Leaf area 12 \\
\hline Treatments & WAP $\left(\mathrm{cm}^{2}\right)$ & WAP $\left(\mathrm{cm}^{2}\right)$ & WAP $\left(\mathrm{cm}^{2}\right)$ & WAP $\left(\mathrm{cm}^{2}\right)$ & WAP $\left(\mathrm{cm}^{2}\right)$ & WAP $\left(\mathrm{cm}^{2}\right)$ \\
\hline \multicolumn{7}{|l|}{ Variety (V) } \\
\hline Oba super 2 & 244.00 & 552.70 & 578.50 & 272.80 & 719.00 & 674.00 \\
\hline Suwan 1 & 203.50 & 515.90 & 522.40 & 186.10 & 681.00 & 633.00 \\
\hline LSD & NS & NS & NS & $76.43^{*}$ & NS & NS \\
\hline \multicolumn{7}{|l|}{ Grades (G) } \\
\hline$A$ & 248.80 & 564.70 & 595.10 & 220.00 & 694.00 & 660.00 \\
\hline B & 220.30 & 541.10 & 530.20 & 233.60 & 732.00 & 662.00 \\
\hline C & 202.20 & 497.20 & 526.10 & 234.70 & 674.00 & 638.00 \\
\hline LSD & NS & NS & $55.07^{*}$ & NS & NS & NS \\
\hline \multicolumn{7}{|l|}{$\begin{array}{l}\text { Rates }(R)(t \\
\text { ha-1) }^{-1}\end{array}$} \\
\hline 0 & 190.10 & 489.60 & 494.30 & 163.90 & 612.00 & 544.00 \\
\hline 2.5 & 235.60 & 561.60 & 571.80 & 290.30 & 735.00 & 690.00 \\
\hline 5 & 245.50 & 551.80 & 585.30 & 234.10 & 753.00 & 727.00 \\
\hline LSD & $22.62^{\star *}$ & $27.46^{* *}$ & $33.65^{\star *}$ & $33.27^{* *}$ & $72.90^{* *}$ & $50.80^{* *}$ \\
\hline$V \times G$ & NS & NS & NS & NS & NS & NS \\
\hline$V \times R$ & NS & NS & NS & NS & $108.50^{*}$ & $84.20^{* *}$ \\
\hline$G \times R$ & NS & NS & NS & $58.74^{* *}$ & $144.60^{*}$ & $109.70^{*}$ \\
\hline$V \times G \times R$ & NS & NS & NS & NS & NS & $146.80^{* *}$ \\
\hline
\end{tabular}

LSD-Least Significant Difference, NS-Not significant, WAP- Weeks after Planting, ${ }^{*} P<0.05,{ }^{* *} P<0.01$ 
Table 4: Effect of organo-mineral fertiliser grade and application rate on leaf area index of maize cultivars at 4, 8, 12 WAP (2014 and 2015$)$

\begin{tabular}{|c|c|c|c|c|c|c|}
\hline & \multicolumn{3}{|c|}{2014} & \multicolumn{3}{|c|}{2015} \\
\hline & Leaf area index & Leaf area index & Leaf area index & Leaf area index & Leaf area index & Leaf area index \\
\hline Treatments & 4 WAP & 8 WAP & 12 WAP & 4 WAP & 8 WAP & 12 WAP \\
\hline \multicolumn{7}{|l|}{ Variety $(\mathrm{V})$} \\
\hline Oba super 2 & 0.58 & 1.84 & 0.15 & 0.62 & 2.32 & 2.01 \\
\hline Suwan 1 & 0.46 & 1.65 & 0.14 & 0.40 & 2.16 & 1.80 \\
\hline LSD & NS & NS & NS & NS & NS & NS \\
\hline \multicolumn{7}{|l|}{ Grades $(G)$} \\
\hline A & 0.60 & 1.85 & 0.16 & 0.48 & 2.26 & 1.91 \\
\hline$B$ & 0.50 & 1.77 & 0.14 & 0.52 & 2.38 & 1.89 \\
\hline C & 0.46 & 1.63 & 0.14 & 0.54 & 2.08 & 1.92 \\
\hline LSD & NS & NS & NS & NS & NS & NS \\
\hline \multicolumn{7}{|l|}{$\begin{array}{l}\text { Rates }(R)(t \\
\text { ha-1) }^{-1}\end{array}$} \\
\hline 0 & 0.40 & 1.52 & 0.13 & 0.37 & 1.90 & 1.58 \\
\hline 2.5 & 0.56 & 1.85 & 0.15 & 0.63 & 2.42 & 2.07 \\
\hline 5 & 0.59 & 1.88 & 0.16 & 0.54 & 2.41 & 2.07 \\
\hline LSD & $0.07^{\star *}$ & $0.10^{* *}$ & $0.01^{* *}$ & $0.01^{\star *}$ & $0.31^{* *}$ & $18.00^{\star \star}$ \\
\hline$V \times G$ & NS & NS & NS & $0.19^{* *}$ & NS & $9.00^{\star *}$ \\
\hline$V \times R$ & NS & NS & NS & NS & $0.43^{\star *}$ & $0.41^{\star \star}$ \\
\hline$G \times R$ & NS & NS & NS & $0.16^{\star *}$ & NS & $0.31^{* *}$ \\
\hline$V \times G \times R$ & NS & NS & NS & NS & NS & $0.49^{\star *}$ \\
\hline
\end{tabular}

LSD-Least Significant Difference, NS-Not significant, WAP- Weeks after Planting, ${ }^{*} P<0.05,{ }^{* *} P<0.01$ 
Table 5: Effect of organo-mineral fertiliser grade and application rate on days to $50 \%$ tasseling, silking and Anthesis-silking interval of maize cultivars (2014 and 2015)

\begin{tabular}{|c|c|c|c|c|c|c|}
\hline \multirow[b]{2}{*}{ Treatments } & \multicolumn{3}{|c|}{2014} & \multicolumn{3}{|c|}{2015} \\
\hline & $\begin{array}{l}\text { Days to } 50 \% \\
\text { Tasseling } \\
\text { (days) }\end{array}$ & $\begin{array}{c}\text { Days to } 50 \\
\% \text { Silking } \\
\text { (days) }\end{array}$ & $\begin{array}{l}\text { Anthesis - silking interval } \\
\text { (days) }\end{array}$ & $\begin{array}{l}\text { Days to } 50 \% \\
\text { Tasseling (days) }\end{array}$ & $\begin{array}{l}\text { Days to } 50 \% \\
\text { silking (days) }\end{array}$ & Anthesis-silking interval (days) \\
\hline \multicolumn{7}{|l|}{ Variety (V) } \\
\hline Oba super 2 & 56.00 & 62.44 & 6.44 & 59.52 & 69.74 & 10.22 \\
\hline Suwan 1 & 57.30 & 64.78 & 7.48 & 60.33 & 72.52 & 12.19 \\
\hline LSD & NS & NS & NS & NS & NS & NS \\
\hline \multicolumn{7}{|l|}{ Grade (G) } \\
\hline A & 56.06 & 63.22 & 7.17 & 59.22 & 70.83 & 11.61 \\
\hline B & 57.50 & 66.33 & 8.83 & 60.50 & 72.39 & 11.89 \\
\hline c & 56.39 & 61.28 & 4.89 & 60.06 & 70.17 & 10.11 \\
\hline LSD & $18.00^{*}$ & $2.83^{* *}$ & NS & NS & NS & NS \\
\hline \multicolumn{7}{|l|}{$\begin{array}{l}\text { Rate }(R)(t \text { ha- } \\
\text { 1) }\end{array}$} \\
\hline 0 & 57.33 & 64.89 & 7.56 & 61.61 & 74.33 & 12.72 \\
\hline 2.5 & 56.33 & 62.61 & 6.28 & 58.72 & 70.28 & 11.56 \\
\hline 5 & 56.28 & 63.33 & 7.06 & 59.44 & 68.78 & 9.33 \\
\hline LSD & $18.00^{*}$ & NS & $2.07^{* \star}$ & $1.90^{* *}$ & $2.13^{\star *}$ & NS \\
\hline$V \times G$ & NS & NS & NS & NS & NS & NS \\
\hline$V \times R$ & NS & NS & NS & NS & NS & NS \\
\hline$G \times R$ & NS & NS & NS & NS & NS & NS \\
\hline$V \times G \times R$ & NS & NS & NS & NS & $8.40^{*}$ & NS \\
\hline
\end{tabular}

LSD-Least Significant Difference, NS-Not significant, * $P<0.05,{ }^{* *} P<0.01$ 
Table 6: Effect of organo-mineral fertiliser grade and application rate on stover weight, shelling percentage and harvest index of maize cultivars (2014 and 2015)

\begin{tabular}{|c|c|c|c|c|c|c|}
\hline & & 2014 & & 201 & & \\
\hline Treatments & $\begin{array}{c}\text { Harvest index } \\
(\%)\end{array}$ & $\begin{array}{l}\text { Stover weight (kg ha- } \\
\text { 1) }\end{array}$ & Shelling percentage (\%) & $\begin{array}{l}\text { Harvest index } \\
\text { (\%) }\end{array}$ & Stover weight $\left(\mathrm{kgha}^{-1}\right)$ & Shelling percentage $(\%$ \\
\hline \multicolumn{7}{|l|}{ Variety $(\mathrm{V})$} \\
\hline Oba super 2 & 31.19 & 4452.00 & 72.73 & 37.60 & 3844.00 & 82.90 \\
\hline Suwan 1 & 32.90 & 3900.00 & 73.92 & 24.20 & 3887.00 & 66.70 \\
\hline LSD & NS & NS & NS & $5.96^{* *}$ & NS & NS \\
\hline \multicolumn{7}{|l|}{ Grade (G) } \\
\hline A & 30.97 & 4587.00 & 72.18 & 34.50 & 3756.00 & 72.10 \\
\hline B & 31.00 & 4056.00 & 74.10 & 26.10 & 3868.00 & 85.70 \\
\hline c & 34.16 & 3884.00 & 73.71 & 32.10 & 3972.00 & 66.60 \\
\hline LSD & NS & NS & NS & NS & NS & NS \\
\hline \multicolumn{7}{|l|}{$\begin{array}{l}\text { Rate }(R) \text { (t ha- } \\
\text { 1) }\end{array}$} \\
\hline 0 & 29.28 & 3209.00 & 70.64 & 25.60 & 3356.00 & 65.90 \\
\hline 2.5 & 31.84 & 4870.00 & 74.59 & 35.90 & 4409.00 & 94.00 \\
\hline 5 & 35.02 & 4449.00 & 74.76 & 31.20 & 3831.00 & 64.60 \\
\hline LSD & NS & $443.10^{* *}$ & $3.56^{*}$ & NS & $825.20^{*}$ & NS \\
\hline$V \times G$ & NS & NS & NS & $9.11^{* *}$ & NS & NS \\
\hline$V \times R$ & NS & NS & NS & NS & NS & NS \\
\hline$G \times R$ & NS & NS & NS & NS & NS & NS \\
\hline$V \times G \times R$ & NS & NS & NS & NS & NS & NS \\
\hline
\end{tabular}

LSD-Least Significant Difference, NS-Not significant, ${ }^{*} P<0.05,{ }^{* *} P<0.01$ 
Table 7: Effect of organo-mineral fertiliser grade and application rate on 100 grain weight, cob weight and grain yield of maize cultivars (2014 and 2015)

\begin{tabular}{|c|c|c|c|c|c|c|}
\hline \multirow[b]{2}{*}{ Treatments } & \multicolumn{3}{|c|}{2014} & \multicolumn{3}{|c|}{2015} \\
\hline & 100 grain yield (g) & Cob weight (kg) & Grain yield (kg ha-1) & 100 grain yield $(\mathrm{g})$ & Cob weight $(\mathrm{kg})$ & Grain yield (kg ha-1) \\
\hline \multicolumn{7}{|l|}{ Variety (V) } \\
\hline Oba super 2 & 11.53 & 1.02 & 2417.00 & 7.13 & 0.08 & 1655.00 \\
\hline Suwan 1 & 10.32 & 0.88 & 2076.00 & 5.09 & 0.05 & 1056.00 \\
\hline LSD & NS & NS & NS & $1.32^{* *}$ & $0.01^{* *}$ & $267.00^{* *}$ \\
\hline \multicolumn{7}{|l|}{ Grade (G) } \\
\hline A & 11.51 & 1.04 & 2466.00 & 6.38 & 0.06 & 1378.00 \\
\hline B & 10.11 & 0.90 & 2129.00 & 5.42 & 0.05 & 1205.00 \\
\hline C & 11.16 & 0.91 & 2144.00 & 6.52 & 0.07 & 1483.00 \\
\hline LSD & NS & NS & NS & NS & NS & NS \\
\hline \multicolumn{7}{|c|}{$\begin{array}{l}\text { Rate }(R)(t \text { ha- } \\
\text { 1) }\end{array}$} \\
\hline 0 & 8.13 & 0.59 & 1368.00 & 4.96 & 0.05 & 908.00 \\
\hline 2.5 & 12.50 & 1.10 & 2615.00 & 6.68 & 0.08 & 1770.00 \\
\hline 5 & 12.14 & 1.16 & 2757.00 & 6.69 & 0.07 & 1388.00 \\
\hline LSD & $1.62^{*}$ & $0.15^{* *}$ & $366.10^{* *}$ & $0.93^{* *}$ & $0.01^{* *}$ & $332.40^{* *}$ \\
\hline$V \times G$ & NS & NS & NS & NS & NS & NS \\
\hline$V \times R$ & NS & NS & NS & NS & NS & NS \\
\hline$G \times R$ & NS & NS & NS & NS & NS & NS \\
\hline$V \times G \times R$ & NS & NS & NS & NS & NS & NS \\
\hline
\end{tabular}

LSD-Least Significant Difference, NS-Not significant, ${ }^{*} P<0.05,{ }^{*}{ }^{*} P<0.01$ 


\section{DISCUSSION}

The result of the trial showed that in both years it was observed that the hybrid maize cultivar (Oba super 2) outperformed OPV in growth, yield attributes and grain yield. The significantly higher assimilatory surface as indicated by high leaf area at 4 WAP in the hybrid cultivar compared to the OPV could have increased its capability of intercepting more radiant energy. This capability could have positively affected carbon assimilatory process. This observation is consistent with Tollenaar and Lee, (2006), who observed that higher assimilatory surface at pre-silking period could support accumulation of dry matter in hybrid maize cultivars. Duncan et al., (1967) suggested that the higher assimilatory surface observed in hybrid maize was accompanied by changes in leaf orientation (erectophile orientation) that could aid even distribution of light into the lower strata of the canopy, thus reducing shade induced senescence (Massignam, 2003). Other physiological implication of this observation could be to increase radiation use efficiency as reported by Lindquist et al., (2005). A significantly higher grain yield observed in the hybrid maize than the OPV could be attributed to the significantly higher 100 grain weight, cob weight and harvest index. Otegui and Bonhomme, (1998) attributed increased ear growth observed in hybrid maize to increased dry matter accumulation and photosynthesis at grain filling period and its eventual partitioning to the ear. Partitioning of assimilates to the ear suggested that there could be an increased kernel set in the hybrid than OPV maize cultivars. This was reflected in reduced ASI (Otegui and Bonhomme, 1998; Vega et al., 2001). A non-significant reduction in ASI was equally observed in our trials, which is consistent with earlier made observation. Though not replicated in 2014 a significantly higher harvest index observed in hybrid maize than OPV in 2015 could have suggested the effect of environmental variability on this yield component. Similar opinion on the effect of harvest index on the yield increase of maize was also reported by Tollenaar and Lee, (2006). In addition they opined that genetic contributions to yield improvement of maize accounted for $75 \%$. They observed that these hybrid maize cultivars had a higher yield potential, resource use efficiency and tolerance to stress than OPV in the corn belt of United States. Chiduza et al., (1996) also reported that hybrid maize had significantly higher yield than OPV by $19 \%$ and $16 \%$ without and with fertiliser application respectively. The better performance of Oba super 2 than Suwan 1 in the site $B(2015)$ than site $A$ (2014) could be attributed to the differences in physical and chemical properties of the sites where the experiments were established. The fertility status of site $B(2015)$ indicated that it had higher soil organic matter with more available $\mathrm{P}, \mathrm{Ca}, \mathrm{Mg}$ and lower $\mathrm{Na}$ than site $\mathrm{A}$ in 2014 to support growth and development of hybrid maize. 
The significantly larger leaf area observed in 2014 at 12 WAP when organo-mineral fertiliser grade A was applied compared to other grades could have indicated that despite its comparatively lower nutrient concentration than other grades of organo-mineral fertiliser, soil $\mathrm{N}$ and $\mathrm{K}$ in that site $\mathrm{A}$ (2014) could have complimented this observed nutrient shortfall and supported the growth and development of maize cultivars. The high concentration of these nutrients in site $\mathrm{A}$ in that year could have reduced the uptake of $\mathrm{Cu}$ and $\mathrm{Mg}$ through antagonistic relationship of mineral nutrients. However, the high concentration of $\mathrm{Cu}$ and $\mathrm{Mg}$ in grade Aorgano-mineral fertiliser suggested a more balanced nutrition for maize cultivars. Balanced nutrition could also have been augmented by the available $P$ in that grade of organo-mineral fertiliser which is comparable to other grades to compliment the inherently low soil $P$ observed. The prevailing textural class of the soil in site $A$ in that year that could predispose the soil to retain more nutrient, make nutrient and water readily available and increased soil microbial activity. It could be suggested that the high concentration of soil nitrogen contained in site A (2014) could have resulted in significantly higher assimilatory surface observed. Nitrogen deficiency had been implicated in leaf growth, activity of Ribulosebiphosphate carboxylase/oxygenase and the rate of hormone synthesis (Andrade et al., 2002; Jones and Setter, 2000). Potassium had also been implicated in reduced stalk lodging, increased stomatal conductance, increased photosynthetic capacity, protein uptake of $\mathrm{K} / N O_{3}$ ion and turgor pressure (Pettigrew, 2008). Increased turgor and reduced lodging could facilitate increased assimilatory surface and increased diffusion of radiant energy into the canopy of maize cultivar. A delayed reproductive development (tasselling and silking) observed in maize cultivars when sown with grade $B$ organo-mineral fertiliser in the site $A$ (2014) could have compromised the reproductive growth of these maize cultivars, .which resulted to an increase in vegetative growth at the expense of the reproductive growth. One of such factor that could predispose maize cultivars to increased vegetative growth in site $A$ (2014) could be attributed to the availability of nutrients from this grade of organo-mineral fertiliser and that of the soil. Observed leaf area response at 12 WAP in site A (2014) could have suggested that grade $B$ organo-mineral fertiliser occupying intermediate position in the composition of macronutrients, with comparatively high concentration of $\mathrm{N}$ and $\mathrm{K}$ in the soil in site A (2014) could have explained the observed growth and development responses of maize cultivars. Jones et al., (1996) attributed delayed silking to nitrogen deficiency; however luxury consumption of $\mathrm{N}$ could equally facilitate increased vegetative growth at the expense of reproductive growth. 
Increased application rates of organo-mineral fertiliser resulted in increased assimilatory surface in both years (site $A$ and $B$ ). This could have aided interception of more radiant energy and photosynthetic capacity of maize cultivars sown at higher application rates. A higher application rate of organo-mineral fertiliser could have resulted in the availability of more nutrients for the growth and development of maize cultivars. Sangoi et al., (2001) posited that increased availability of nitrogen to maize plants would aid their photosynthetic capacity. Improved availability of nitrogen could also have been implicated in the early flowering observed at increased application rate of organo-mineral fertiliser. Tollenaar et al., (1994) reported that nitrogen deficiency in maize crop is capable of delaying silking. It was suggested that this could have resulted from the protandrous development observed when there was nitrogen deficiency in maize (Earl and Tollenaar, 1997; Jones et al., 1996). Apical dominance had also been implicated under this condition, resulting in tassel development, increased ASI and a delayed silking. By extension there is the possibility of barrenness and reduced grain yield in maize. However in this investigation, increased application rates of organo-mineral fertiliser resulted in a converse pattern on growth, development and grain yield of maize. This was evidenced in increased cob weight, 100 grain weight and grain yield observed in both years. This pattern was consistent with the observation made by Onasanya et al., (2009), where optimum growth of maize was observed at $120 \mathrm{~kg} \mathrm{~N} \mathrm{ha}^{-1}+40 \mathrm{~kg} \mathrm{P}^{\mathrm{P}} \mathrm{h}^{-1}$ that gave the highest grain yield in the humid tropics of Nigeria. In cucumber Olaniyi et al., (2009) observed that application rates of organo-mineral fertiliser in the range 2-4 t ha-1 resulted in a significant increase in the growth, yield and nutrient uptake of cucumber. This was equally corroborated by Arunah and Ibrahim, (2004), where it was observed that combined application of inorganic and organic fertiliser gave the highest performance in sorghum grown in the Guinea savanna zone of Nigeria. Other nutrients that could be made available at a higher application rates like $\mathrm{P}$ and $\mathrm{K}$ could also be implicated in the pattern of growth, development and grain yield observed. Plénet et al., (2000) had observed the effect of $P$ on growth of maize through increased assimilatory surface, radiation use efficiency and biomass accumulation. Pettigrew, (2008) also reported the implication of $\mathrm{K}$ on photosynthetic capacity of maize, leaf growth and transportation of assimilates.

\section{CONCLUSION}

There was a significant varietal variation on growth, yield attributes and grain yield of maize at site $B$ in 2015. In that year maize hybrid Oba super 2 had significantly more assimilatory surfaces than OPV maize cultivar (Suwan 1). This observation could have suggested 
interception of more radiant energy to facilitate canopy photosynthesis. This was reflected in 100 grain weight, ear weight and harvest index that could have contributed to the better performance of this hybrid variety in site $B(2015)$ than OPV. The better performance of Oba super 2 than Suwan 1 in site B (2015) than site A (2014) could be attributed to the differences in physical and chemical properties of the sites where the trials were established. Maize cultivars in which grade B organo-mineral fertiliser was applied but had delayed tasselling and silking compared to other grades in the year 2014 (site A). A comparatively high availability of macro and micronutrients from this grade of organo-mineral fertiliser could have increased vegetative growth (leaf area at 12 WAP) at the expense of reproductive growth which could have resulted in a delayed flowering. Increasing application rates of organo-mineral fertiliser resulted in increased assimilatory surface that could have aided the availability of assimilates for the growth of reproductive organs (100 grain weight and cob weight) and improved grain yield ha-1 in both years (sites $A$ and $B$ ). Faster rate of development observed in both years with increasing application rates of organo-mineral fertiliser could have suggested increased availability of assimilates for the reproductive growth.

\section{ACKNOWLEDGEMENTS}

Technical assistance was provided by Dr A.A. Soretire of the Department of Soil Science and Land Management, FUNAAB in compounding grades of organo-mineral fertiliser used. Our profound gratitude goes to Prof K.A. Okeleye, Dr Godwin Ajiboye and Mr P.A.S. Soremi for reviewing the initial draft of this manuscript.

\section{REFERENCES}

Abayomi, Y., George-Arijenja, A. and Kolawole, I. A. (2006). Comparative leaf growth and grain yield responses of hybrid and open-pollinated maize genotypes to nitrogen fertilizer application. Agrosearch8(1):13-26.

Adenuga, A. H., Omotesho, K. F., Olatinwo, K. B., Muhammad-Lawal, A.and Fatoba, I. (2012). Determinants of fertilizer usage in dry season amaranthus vegetable production in Kwara State, Nigeria. Agrosearch12(2):126-134.

Ainsworth, E. A. (2008). Rice production in a changing climate: a meta-analysis of responses to elevated carbon dioxide and elevated ozone concentration. Global Change Biology14(7):1642-1650. 
Akinrinde, E. A., Bello, O. S., Ayegboyin, K. O. and Iroh, L. (2005). Added benefits of combined organic and mineral phosphate fertilizers applied to maize and melon. Journal of Food Agriculture and Environment, 3(3/4):75.

Allison, L. (1965). Organic carbon. In C.A Black (Ed.), Methods of soil analysis. Part 2 (pp. 1307-1378). Madison: American Society of Agronomy.

Andrade, F. H., Echarte, L., Rizzalli, R., Della Maggiora, A. and Casanovas, M. (2002). Kernel number prediction in maize under nitrogen or water stress. Crop Science42(4):1173-1179.

Arunah, U. L. and Ibrahim, H. (2004). Effects of inorganic fertilizer and poultry manure on sorghum yield at Samaru in the Northern Guinea Savanna of Nigeria. Agrosearch6(1-2): 49-54.

Borrás, L., Slafer, G. A. and Otegui, M. E. (2004). Seed dry weight response to source-sink manipulations in wheat, maize and soybean: a quantitative reappraisal. Field Crops Research86(2):131-146.

Chiduza, C., Waddington, S. R.and Mariga, I. K. (1996). Grain yield and economic performance of experimental open-pollinated varieties and released hybrids of maize in a remote semi-arid area of Zimbabwe. Retrieved from http://repository.cimmyt.org:8080/xmlui/handle/10883/1953

Duncan, W. G., Loomis, R. S., Williams, W. A. and Hanau, R. (1967). A model for simulating photosynthesis in plant communities (Vol. 38). University of Calif. Retrieved from http://californiaagriculture.ucanr.org/landingpage.cfm?article=hilg.v38n04p181\&abstr act=yes

Dwyer, L. and Stewart, D. . (1986). Leaf area development in field grown maize. Agronomy Journal78: 334-343.

Earl, H. J. and Tollenaar, M. (1997). Maize leaf absorptance of photosynthetically active radiation and its estimation using a chlorophyll meter. Crop Science37(2):436-440.

Hammer, G. L., Dong, Z., McLean, G., Doherty, A., Messina, C., Schussler, J. and Cooper, $M$. (2009). Can changes in canopy and/or root system architecture explain historical maize yield trends in the US corn belt? Crop Science49(1):299-312.

Jackson, M. (1962). Soil chemical analysis. New Delhi: Prentice Hall of India Pvt, Ltd. pages 498

Jones, R. J., Schreiber, B. and Roessler, J. A. (1996). Kernel sink capacity in maize: genotypic and maternal regulation. Crop Science36(2):301-306. 
Jones, R. and Setter, T. (2000). Hormonal regulation of early kernel development. In M. Westgate \& K. Boote (Eds.), Physiology and modelling kernel set in maize (pp. 2542). Madison, WI: CSSA.

Landor, J. (1991). Brooker tropical soil manual. A handbook for soil survey in the tropics and subtropics. England: Longman Group.pp106-144

Lathwell, D. J. and Grove, T. L. (1986). Soil-plant relationships in the tropics. Annual Review of Ecology and Systematics 17(1):1-16.

Lindquist, J. L., Arkebauer, T. J., Walters, D. T., Cassman, K. G. and Dobermann, A. (2005). Maize radiation use efficiency under optimal growth conditions. Agronomy Journal97(1):72-78.

Massignam, A. (2003). Qunatifying nitrogen effects on crop growth processes in maize and sunflower $(\mathrm{PhD})$. University of Queensland, Brisbane.

McLean, E. O. (1982). Soil pH and lime requirement. Methods of Soil Analysis. Part 2. Chemical and Microbiological Properties, (methodsofsoilan2), 199-224.

Olaniyi, J. O., Ogunbiyi, E. M. and Alagbe, D. D. (2009). Effects of organo-mineral fertilizers on growth, yield and mineral nutrients uptake in cucumber. Journal of Animal \& Plant Sciences5(1):437-442.

Onasanya, R. O., Aiyelari, O. P., Onasanya, A., Oikeh, S., Nwilene, F. E. and Oyelakin, O. O. (2009). Growth and yield response of maize (Zea mays L.) to different rates of nitrogen and phosphorus fertilizers in southern Nigeria. World Journal of Agricultural Sciences5(4): 400-407.

Otegui, M. E. and Bonhomme, R. (1998). Grain yield components in maize: I. Ear growth and kernel set. Field Crops Research56(3):247-256.

Payne, R., Murray, D., Harding, S., Baird, D. and Soutar, D. (2009). Genstat for Windows (12th Edition) Introduction. Hemel Hempstead: VSN International.

Pettigrew, W. T. (2008). Potassium influences on yield and quality production for maize, wheat, soybean and cotton. Physiologia Plantarum133(4):670-681.

Plénet, D., Mollier, A.and Pellerin, S. (2000). Growth analysis of maize field crops under phosphorus deficiency. II. Radiation-use efficiency, biomass accumulation and yield components. Plant and Soil224(2):259-272.

Sangoi, L., Ender, M., Guidolin, A. F., Almeida, M. L. de, and Konflanz, V. A. (2001). Nitrogen fertilization impact on agronomic traits of maize hybrids released at different decades. Pesquisa Agropecuária Brasileira36(5):757-764.

Tollenaar, M.and Lee, E. A. (2006). Dissection of physiological processes underlying grain yield in maize by examining genetic improvement and heterosis. Maydica51(2):399. 
Tollenaar, M., McCullough, D. and Dwyer, L. (1994). Physiological basis of genetic improvement of corn. In G. Slafer (Ed.), Genetic improvement of field crops (pp. 183236). M. Dekker.

Vega, C. R. C., Andrade, F. H.and Sadras, V. O. (2001). Reproductive partitioning and seed set efficiency in soybean, sunflower and maize. Field Crops Research72(3): 163175. 